\title{
The Role of Teachers in Implementation Social Care Education Character at Primary Schools
}

\author{
Mazda Leva Okta Safitri ${ }^{1}$, Ali Mustadi ${ }^{2}$, Heri Retnawati ${ }^{3}$ \\ 1,2,3 Universitas Negeri Yogyakarta, Indonesia
}

Mazdaleva.2019@student.uny.ac.id

\begin{tabular}{|c|c|}
\hline \multirow{3}{*}{$\begin{array}{l}\text { ARTICLE INFO } \\
\text { Article history: } \\
\text { Received } \\
\text { January 06, } 2021 \\
\text { Revised } \\
\text { February 01, } 2021 \\
\text { Accepted } \\
\text { July 12, } 2021\end{array}$} & ABSTRACT \\
\hline & $\begin{array}{l}\text { One of the most important characters and must be implemented by } \\
\text { students is the character of social care. The teacher has a very important } \\
\text { role in impntation of characters in schools. This study aims to describe } \\
\text { the role of teachers in the implementation of social care character } \\
\text { education in elementary schools. This type of research is a qualitative } \\
\text { research with a phenomenological type. The researchers conducted } \\
\text { interviews and gave questionnaires to } 32 \text { primary teachers in South } \\
\text { Sumatra Province. The results of this study indicated that the teacher } \\
\text { instills a social care character in the classroom by integrating social care } \\
\text { character into learning materials and becoming good role models for } \\
\text { students. Teachers also give punishment and rewards in order to } \\
\text { encourage and discipline students. Teachers and schools have also } \\
\text { carried out various activities to instill social care in students. It has also } \\
\text { received support from many parents of students. To make social caring } \\
\text { character education run optimally, several ways can do by the teacher is } \\
\text { that the lesson plan that is made must be considered and by the elements } \\
\text { of education, making study contracts and further increasing parental } \\
\text { participation in students' social activities. }\end{array}$ \\
\hline & $\begin{array}{l}\text { Keywords: Social Care Education Character, Education Character, The Role of } \\
\text { Teacher }\end{array}$ \\
\hline How to cite & $\begin{array}{l}\text { Safitri, M., Mustadi, A., \& Retnawati, H. (2021). The Role of Teachers in } \\
\text { Implementation Social Care Character Education at Primary Schools. Jurnal Iqra' } \\
\text { : Kajian Ilmu Pendidikan, 6(2). 39-50. https://doi.org/10.25217/ji.v6i2.1315 }\end{array}$ \\
\hline Journal Homepage & http://journal.iaimnumetrolampung.ac.id/index.php/ji/ \\
\hline - & $\begin{array}{l}\text { ticle under the CC BY SA license } \\
\text { https://creativecommons.org/licenses/by-sa/4.0/ }\end{array}$ \\
\hline
\end{tabular}

\section{INTRODUCTION}

Education character has the aim of planting values in students and reforming the common life order that values individual freedom more (Maunah, 2016). As social beings (homo socialists), humans do not only rely on their strengths, but need other humans in certain ways, and must respect, love, and care for various kinds of circumstances around them (Tabi'in, 2017). Sudrajat (2011) explained that good character is related to knowing the good, loving the good, and doing the good. Character education is a deliberate implementation to regulate behavior by the values of humanity and organized to train individuals who succeed academically (Katilmis et al., 2011). Character education in Indonesia is a national movement to create schools in fostering ethical, responsible young generations because character education places more emphasis on universal value aspects (Maunah, 2016). The effectiveness of character education is very much determined by the existence of teaching, modeling, 
reinforcing, and habituating which are carried out simultaneously and continuously (Sudrajat, 2011).

The results of research conducted by Katilmis et al. (2011) revealed that 1) The character education program affects students' knowledge, skills, and behavior towards scientific values in a positive way, 2) The character education program contributes to students informing sensitive and tolerant characters and against violent behavior, 3 ) Character education programs have a positive effect on students' academic achievement.In order to form a mature personal character, there should be continuous and continuous process throughout life (Darmayanti \& Wibowo, 2014). The existing social situation is the main reason for character education to be implemented immediately in educational institutions (Sari, 2016). The characters that must be developed in school are religiousity, honesty, tolerance, discipline, hard work, creativity, independence, democratic, curiosity, patriotism, nationalism, achievement apprection, being friendly or communicative, love of peace, fondness of reading, environmental awereness, social care, and responsibility. Social care is an act of caring for the surrounding social environment so that it makes students always motivated to help others in need. By caring socially students not only have an understanding of the importance of helping can take action to help others in need (Fauzi et al., 2017). The involvement of students in character education towards education in social competence is in line with cognitive development or a just community approach to moral education (Cheung \& Lee, 2010).

Social care as one of the cores in the implementation of character education is the attitude and actions that always want to assist other people and communities in need (Agung \& Asmira, 2018). In today's era, students need to be introduced and even taught about social care, so that one day students will have sensitivity to people in need. By introducing the values of caring, students will know and understand the importance of caring for others. It will benefit students and the nation when it is taught seriously (Tabi'in, 2017). The contribution of the character education program will depend on the involvement of students in the program (Cheung \& Lee, 2010)

Based one the data obtained from the Indonesian Child Protection Commission of Indonesia (KPAI), there are 153 report of physical and psychological violence towards students in educational units in 2019. There are students whp became victims of policies, physical violence and bullying. In total, 39 percent of violence physical and bullying occurs at primary school (KPAI, 2019). This data shows that many students still have very low social awareness. Intercourse in society has shifted from a society that emphasizes a sense of social to asocial. This is due to the many bad influences of foreign values that have entered Indonesian territory without going through the filtering process. This bad influence, if left unchecked, will certainly damage the morale of the younger generation, especially students (Maunah, 2016). The current conditions and situation seem to require character education that needs to be transformed from an early age, namely from early childhood education, primary education, secondary education, and higher education holistically and continuously (Budiwibowo, 2013).

Activities that can be carried out by teachers to instill a character of social care are by integrating social care values into teaching and learning activities in the classroom (Sari 2016). In order to achieve the successful character education, teacher should prepare, implement, and evaluate character education well (Sidauruk \& Supeni, 2019). The teacher must also educate students to have a verbal and nonverbal social care character. Verbal value inculcation is a way to instill the value of social care 
through giving motivation, advice, stories, reprimands (such as oral and written), prohibitions (such as mild, moderate, severe), and praise, while nonverbal methods are through habitual behavior, and role models (Octavia, Tri, 2019). Teachers must also collaborate with schools and parents to facilitate social activities, take social action, provide facilities to donate, empathize with fellow school members, and build class community harmony (Hendriana \& Jacobus 2017).

In several previous studies, it has been explained how to carry out social care character education, but it does not see how the actual implementation is in elementary schools. Through this research, readers not only know how to implement but also know how the actual implementation of social care character education runs in elementary schools. This is something important because sometimes theory and realization have differences.

\section{METHODS}

This research is qualitative research with a type of phenomenology. This study aims to describe the role of teachers in the implementation of social care character education in elementary schools. This research was conducted in October 2020. Data collection techniques in this study used questionnaires and in-depth interviews with 32 elementary school teachers in South Sumatra Province. The questionnaire was conducted using google form. The reseachers also conducted in-depth interviews with several teachers to strengthen the research results.

Teacher who were involved in this research participated voluntary and without coercion. The data obtained from the results of questionnaires and interviews will only be used in this study and will not affect future research subjects. The stages of data analysis in this study were data reduction, data display, and drawing/verification. In the reduction stage, the researcher distinguishes which ones are needed in the study and which ones should be deleted, so that the research results are more focused. Next, in the display stage, the researcher will present the reduced data into tables and short statements. Last, in the drawing/verification stage, the researcher will make conclusions. The conclusion is a description that explains the results of the data that has been obtained.

\section{RESULT AND DISCUSSION}

Teachers have an important role in implementing character education, one of which is the character of social care. First, teachers integrate character development in teaching and learning activities in the classroom (Sari 2016). Second, teachers must also educate students to have a social care character (Octavia, Tri, 2019). And lastly, teachers must also collaborate with schools and parents to facilitate social activities (Hendriana \& Jacobus 2017).

A. Integration in teaching and learning activities

Three activities must be carried out by teachers in integrating character education with learning activities. The planning stage is the first stage that must be carried out. Uno (Apriyanti, 2017) explained that planning is a satisfying way to make activities run well, accompanied by various anticipatory steps to minimize gaps that occur so that these activities achieve the stated goals. Based on the results of the study, it shows that the teacher plans social care character education by adjusting it with basic competencies (KD), indicators, and learning materials that will be carried out in learning activities. 
Table 1. Interview Results Regarding the Planning Stage

\begin{tabular}{lrl}
\hline No. & Informant & \multicolumn{1}{c}{ Interview Results } \\
\hline 1. & Informant 1 & $\begin{array}{l}\text { By linking the material with daily activities. } \\
\text { By reviewing the existing material, then the teacher can } \\
\text { pour character education with a social care attitude in } \\
\text { learning activities. } \\
\text { By linking with the basic competencies and indicators that I } \\
\text { have made according to the theme being studied. }\end{array}$ \\
\hline
\end{tabular}

Based on the results of the questionnaire, some teachers stated that they always included social caring character education in each lesson plan (RPP). Meanwhile, some teachers also stated that sometimes they included social caring character education which had to be adjusted to existing learning materials so that it could not always be included in the lesson plan (RPP). The researcher also conducted in-depth interviews with one of the teachers to ask whether the teacher specifically included social caring character education in the lesson plan (RPP) and the teacher stated that he only followed learning material and did not specifically include social caring character education. Next is the implementation stage, the teacher stated that they carry out social care character education by the lesson plan (RPP) that has been made. The teacher also carrid out social care character education by carrying out activities that are by the character of social care.

Table 2. Interview Results Regarding the Implementation Stage

\begin{tabular}{lll}
\hline No. & \multicolumn{1}{c}{ Informant } & \multicolumn{1}{c}{ Interview Results } \\
\hline 1. & Informant 4 & $\begin{array}{l}\text { Children are asked to help each other between friends, } \\
\text { family, and the community according to their abilities. } \\
\text { By integrating and providing social care values in the } \\
\text { learning material. }\end{array}$ \\
3. Informant 5 & Informant 6 & $\begin{array}{l}\text { The way to do it is to teach based on lesspm plan that I } \\
\text { have made. }\end{array}$
\end{tabular}

In the implementation of social caring character education, it is also sometimes carried out without a plan (spontaneously) because various circumstances and situations can occur during the learning process. An example was given by one of the informants "while writing there were students who did not bring pens, so I asked other students who brought more than one pen to lend them".

The last one is the evaluation stage to meansure the success or failure of character education in what is being carried out. Based on the results of interviews through questionnaires, the teacher revealed that there were several obstacles and obstacles both during the planning and implementation of social care character education.

Table 3. Interview Results Regarding the Evaluation Stage

\begin{tabular}{lll}
\hline No. & Informan & \multicolumn{1}{c}{ Interview Results } \\
\hline 1. Informant 7 & $\begin{array}{l}\text { The variety of characters of students makes teachers } \\
\text { feeling constrained in implementing social care character } \\
\text { education. }\end{array}$ \\
2. Informant 8 & $\begin{array}{l}\text { The obstacle may be in understanding the characteristics of } \\
\text { children because instilling character education is not easy, } \\
\text { some children accept it immediately, some are difficult. }\end{array}$
\end{tabular}


3. Informant 9

Because the characteristics of children differ from one another.

The character values developed in schools have not been translated into representative indicators. This unrepresentative and good indicator causes difficulties in measuring its achievement.

Constraints and barriers that teachers often encountered due to the nature, characteristics, ethnic, and cultural backgrounds of each student. The implementation of character education is not necessarily a plan without challenges so that the various challenges faced in the process continue to emerge (Hidayah et al., 2018). Teachers have difficulty measuring the attitudes that students show because the indicators are less representative. One of the teachers also revealed that facilities to support the implementation of social care character education are one of the obstacles in its implementation.

\section{B. Educate}

As a teacher, the researchers educate students by giving examples or role models for students. Based on the results of the questionnaire, the teacher provides an example to students by doing activities that can be exemplified by students such as giving massage to students in need, helping students, visiting students, sharing food, etc. The teacher in carrying out these activities also provides knowledge about the importance of caring for each other.

\begin{tabular}{|c|c|c|}
\hline No. & Informant & Interview Results \\
\hline 1. & Informant 10 & $\begin{array}{l}\text { By explaining to students that everything they do is a very } \\
\text { good example in everyday life. }\end{array}$ \\
\hline 2. & Informant 11 & $\begin{array}{l}\text { By showing and encouraging students to share to each } \\
\text { others as giving food or borrowing pencils to friends who } \\
\text { do not have pencils }\end{array}$ \\
\hline 3. & Informant 12 & $\begin{array}{l}\text { By starting to show concern for the surroundings such as if } \\
\text { a friend falls, you should help him first, not laugh at him }\end{array}$ \\
\hline 4. & Informant 13 & $\begin{array}{l}\text { Starting from me first because it will be imitated by their } \\
\text { students. For example, conducting home visit to students } \\
\text { who are sick and helping students who are in distress. }\end{array}$ \\
\hline 5. & Informant 14 & $\begin{array}{l}\text { By conveying the benefits of caring and being kind to } \\
\text { others, besides the teacher must also provide a good } \\
\text { example so that students can imitate it, for example } \\
\text { helping friends who are in trouble, sharing food, etc. }\end{array}$ \\
\hline
\end{tabular}

If there are students who do not reflect social care, the teacher gives punishment. Punishment is a tool in the world of education that functions as a means of controlling children's behavior (Rofiq, 2017). Educational punishment can be in the form of advice, reprimand, administrative punishment, social punishment, material punishment, and the last alternative is physical punishment (Ma`arif, 2018). 
Table 5. Interview Results Regarding Punishment from Teachers

\begin{tabular}{|c|c|c|}
\hline No. & Informant & Interview Results \\
\hline 1. & Informant 15 & $\begin{array}{l}\text { Give verbal reprimands with kind words and do not offend } \\
\text { students }\end{array}$ \\
\hline 2. & Informant 16 & Advise and pay more attention to them \\
\hline 3. & Informant 17 & $\begin{array}{l}\text { If the student cannot be reprimanded, I will punish } \\
\text { him/her to cleaning the classroom }\end{array}$ \\
\hline 4. & Informant 18 & $\begin{array}{l}\text { Reprimand students in private (not in public), explaining } \\
\text { the harm they get for their behavior. }\end{array}$ \\
\hline 5. & Informant 19 & $\begin{array}{l}\text { I give the advice. When it doesn't work, I called his/her } \\
\text { parents. }\end{array}$ \\
\hline
\end{tabular}

Referring to the results of the questionnaire, the teacher stated that the punishment given to students were in the forms of verbal advice and reprimands. Laters, if students were caught not behaving in the good way, teacher would give nonverbal punishments such as cleaning the class or certain places. The teacher gives punishment by calling parents when students' is out limit. The researcher again conducted an in-depth interview about what kind of incident made the teacher call the student's parents and the teacher stated that there had been an incident where the student did not break up his friend's fight but the student became the provocateur in the fight.

And when the teacher finds a student who shows a social care attitude, the teacher will reward the student. Rewards are given by the teacher to students by giving prizes for positive things done by students. Giving rewards is intended to make children more active in their efforts to work and do better (Ikranagara, 2015). Based on the teacher's opinion through a questionnaire, the teacher gives rewards both verbally and nonverbally.

Table 6. Interview Results Regarding Reward from Teachers

\begin{tabular}{|c|c|c|}
\hline No. & Informant & Interview Results \\
\hline 1. & Informant 20 & By giving praise verbally. \\
\hline 2. & Informant 21 & By giving gift such as be food, books, etc. \\
\hline 3. & Informant 22 & $\begin{array}{l}\text { By giving nonverbal rewards such as (nod, smile, clap, } \\
\text { thumbs up) }\end{array}$ \\
\hline 4. & Informant 23 & $\begin{array}{l}\text { By providing added value to attitude assessment and } \\
\text { provides both verbal and nonverbal rewards. }\end{array}$ \\
\hline 5. & Informant 24 & $\begin{array}{l}\text { By giving reinforcement in the form of praise and stars. If } \\
\text { the stars are successfully collected I will give a reward. }\end{array}$ \\
\hline
\end{tabular}

\section{Cooperation}

Cooperation between teachers with school and parents is important in implementing character education. Based on the results of a questionnaire with the teacher, the teacher stated that the school fully supports all activities that can encourage students to have a social caring character. There are various program activities organized by the school, both in the form of routine and spontaneous activities. There a form of support from school so that students do have a social caring character. 
Table 7. Interview Results Regarding Reward from Teachers

\begin{tabular}{lcl}
\hline No. & Informant & \multicolumn{1}{c}{ Interview Results } \\
\hline 1. & Informant 21 & $\begin{array}{l}\text { I encourage 5S culture (Smile, Say Hello, Say greetings, } \\
\text { Being polite, and Being courteous). }\end{array}$ \\
2. & Informant 22 & $\begin{array}{l}\text { Cooperation activities in, for example, make voluntary } \\
\text { contributions if student members are experiencing a } \\
\text { disaster and also if there is a national disaster. }\end{array}$
\end{tabular}

3. Informant 23 Assembly: a monthly activity to create, lead, and perform

And yaumi charity: prayer, activities to help parents, etc.
4. Informant 24 Implementating of class pickets, encouraging mutual cooperation, conducting visit to students' house who were sick or hit by an accident.

5. Informant 25 In order to teach them the values of sharing and giving, we provided a special piggy bank in each class. We also hold a sharing Friday once in a month.

6. Informant 26 Charity event.

The next support that teachers must get is the support of parents because all forms of activity programs both from teachers and schools must hold permission from the parents of students. Based on the results of the questionnaire, the teacher stated that parents fully supported activities at school that could encourage students to have a social caring character. On the orther students, teacher also revealed that sometimes there were parents who did not provide support, arguing that these activities did not have a clear purpose. There are also parents who were having economical issues.

Table 8. Interview Results Regarding Cooperation with Parents

\begin{tabular}{lrl}
\hline No. & Informan & \multicolumn{1}{c}{ Interview Results } \\
\hline 1. & Informant 27 & $\begin{array}{l}\text { When parents feel difficult in financial problems and when } \\
\text { the purpose of the activity is not clear. }\end{array}$ \\
2. & Informant 28 & $\begin{array}{l}\text { There are some parents who are having economical issues. } \\
\text { Give donations to be used for social services at the } \\
\text { 3. }\end{array}$ \\
Informant 29
\end{tabular}
influences the character of students (Lizawati \& Uli, 2018). Teachers, schools, and parents have their respective roles in character education for students. A teacher reveals that the role of a teacher is to give or shape students to be virtuous, have a polite, caring, responsible personality to friends or to parents/teachers, which of these criteria can serve as guidelines for participant students to become a better person for the future. Most of the teachers in this study also agreed that character education is very important.

The implementation of social caring character education that is integrated with classroom learning has been carried out according to the stages by most of the teachers starting from the planning, implementation, and evaluation stages. It was also found that the teacher also carried out activities without a plan (spontaneously) that were adjusted to the situation in the classroom. Teachers also found obstacles and obstacles in implementing social care character education. However, the teacher revealed that all students can carry out social caring character education properly as long as the teacher provides understanding and socialization about social caring character education, as well as providing guidance, role model, habituation, and supervision from the teacher. 
Seeing directly the attitude showed or observation is the teacher's way of assessing whether the implementation of social caring character education has been going well. In order to conduct evaluation of social care character, teachers used attitude assessment rubrics and self-assessment.

To make social caring character education run optimally, there are several ways that teachers can do, including first, in integrating social caring values education into learning activities, the teacher must prepare lesson plan (RPP) that contains social caring characters. adjusted to basic competencies, indicators, and learning objectives. The use of learning methods can also be used to support social caring character education, one of which is the storytelling method as expressed by Octavia, Tri (2019). Because storytelling can provide unique and interesting learning, and can vibrate the feelings of students, arouse enthusiasm and cause a positive response, especially in stories both work or fiction as well as real stories that exist in everyday life so that students can behave more care for other people and the environment around students (Jumini et al., 2015). In educating, teachers have various ways of implementing them both by providing examples, rewards, and punishments. The teacher acts as a role model for students, both role models at the theoretical and practical levels (Ginanjar, 2017). An example is also given verbally and nonverbally. Verbal role models are usually in the form of good words or utterances expressed to students and school members. Nonverbal role models are usually social activities. In addition to providing examples, the teacher also provides rewards that are tailored to the character and responses of students after being given the reward. Teachers take turns using verbal or nonverbal rewards. The use of this variation is done to avoid boredom and also avoid loss of meaning (Marta, 2016).

Meanwhile, if there are students who do not reflect the character of social care, the teacher will give punishment. The teacher reveals that the punishment is given according to the level of error committed by the student. The punishment that is often used is verbal and rarely uses corporal punishment or calling parents to school. When determining the punishment that should be given to students, the teacher must beforehand agree with students about the bad attitudes that are carried out along with the punishments they should get as a consequence. Therefore, that students know what they will get when doing attitudes that do not reflect social care. As stated by Seftiana, (2019) that teachers and students make a learning contract that contains rules that must be obeyed together. Laws or sanctions for violations must also be obeyed and made jointly between teachers and students.

Finally, cooperation between teachers, schools, and parents is needed so that character education carried out in schools can get optimal results. As explained in the results of the study, both schools and parents provide full support for activities that can improve the character of social care in students. School participation in supporting character education is by holding social activities for students. In addition, parets' support such as monitoring and encouraging students at home and in the community.

Based on several previous descriptions, the researcher found that in integrating social caring character education, the teacher only followed the learning material and did not specifically include social caring character education. Constraints and barriers that teachers often encountered due to the nature, characteristics, ethnic, and cultural backgrounds of each student. Teachers have used role models, punishments, and rewards in educating students to have a socially caring character. Collaboration between teachers and schools and parents makes a major contribution to the implementation of character education for social care. 
Previously, researchers have explained that there are three ways in implementing social care character education. Firstly, integrated character development in teaching and learning activities in the classroom (Sari 2016). Based on the results of research from Octavia Tri (2019), shows that teachers instill the value of social care using a combined model by integrating value planting through lessons and outside of subjects. The same thing is revealed that integration can be done in the substance of the material, learning approaches, and methods, as well as the evaluation model developed (Ansori, 2020). However, in this research, it was found that the teacher only followed the learning material and did not specifically include social care character education. From these findings, the teacher should pay special attention so that they are not fixated on the existing material, but the teacher can add some material based on the learning objectives so that social caring character education can be carried out well in learning.

Second, teachers must also educate students to have a social caring character (Octavia, Tri, 2019). Based on the results of research from Hendriana \& Jacobus (2017), stated that character education in schools can be applied through exemplary by teachers and can also be planted through continuous habituation. However, in this research, it was found that teachers provide role models based on events that occur only and do not have a specific schedule. Tabi'in (2017), states in his research that punishment must be directed and show that the behavior is wrong. Teachers must remember that punishments for students should not be confused with those for adults. In this study, the researcher found that there was no agreement about the actions and consequences of student behavior. The types of rewards and punishments given by the teacher are better at making contracts in their implementation so that students know the consequences of their behavior.

Thirdly, teachers must also collaborate with schools and parents to facilitate social activities (Hendriana \& Jacobus 2017). Irma et al. (2019), said that parents are also involved in various school activities. This is intended so that parents can understand, know, and feel involved in school programs. In line with that, Putri et al. (2020), stated that the high and low motivation of parents will affect the activeness of parents in the educational process of students in educational units. So schools must also take the initiative to continue to maintain active parents in encouraging involvement in student education both at school and at home. In this research, it was found that the teacher had collaborated with the school and parents, but some parents were still reluctant to contribute for several reasons. A good explanation can make parents more confident about the activities carried out and contribute more to its implementation.

This research contributes to provide references for teachers in implementing social care character education. This research also contributes to seeing how the implementation of character education is carried out by teachers in elementary schools. In this study, it can be seen that the implementation of social care character education by teachers has been carried out well, starting from integration with learning, how to educate and collaborate with schools and parents. However, there is still the lack of seriousness of the teacher in its implementation, such as in learning, the teacher has not had the initiative in implementing it and only looks at the existing learning material. Exemplary, punishment, and reward have also been applied properly by the teacher, although punishment and reward have not been contracted in their implementation with students. Cooperation with schools and parents has also been going well, but a good explanation is still needed so that parents are more confident in participating in 
supporting social caring character education by teachers. This research only describes and provides several solutions in the implementation of social care character education for teachers in elementary schools. This study does not yet know how effective the solutions are given.

\section{ACKNOWLEDGMENT}

The author would like to thank 32 elementary school teachers in South Sumatra Province who participated in this research. The author also thanks to the lecturers and students of the primary education department at Yogyakarta State University who have provided suggestions for the results of this research.

\section{AUTHOR CONTRIBUTION STATEMENT}

MLOS (Mazda Leva Okta Safitri) is the main researcher in this research. AM and HR have a role as guidance in conducting this research. Guidance is given from all aspects from the beginning to the end of the research. Submission of this article is done with the permission of AM and HR.

\section{CONCLUSION}

As previously described, the implementation of social caring character education carried out by teachers is known that in instilling a character of social care in the classroom by integrating social values into learning materials. To educate students about social care values, the teacher provided several examples so that students can imitate them. Punishment and rewards were also given to students. Teachers and schools have also carried out various activities to instill social care in students, this has also received support from many parents of students. Several ways can be done by teachers so that the implementation of social care character education can be more optimal. First, the teacher should prepare a lesson plan (RPP) that contains social care characters according to basic competencies, indicators, and learning objectives. Second, about the bad attitudes that are carried out along with the punishments they must get as a consequence so that students know what they will get when doing attitudes that do not reflect caring social. And finally, the form of cooperation is that schools can participate in supporting character education by holding social activities for students while parents can monitor and direct students both at home and in the community.

\section{REFERENCES}

Agung, P., \& Asmira, Y. D. (2018). Pengembangan Model Pendidikan Karakter Peduli Sosial Melalui Metode Bermain Peran di TK Tunas Mekar Indonesia Bandar Lampung. Jurnal Caksana: Pendidikan Anak Usia Dini, 1(02), 139-158. https:// doi.org/10.31326/jcpaud.v1i02.195

Apriyanti, H. (2017). Pemahaman Guru Pendidikan Anak Usia Dini Terhadap Perencanaan Pembelajaran Tematik. Jurnal Obsesi: Jurnal Pendidikan Anak Usia Dini, 1(2), 117. https://doi.org/10.31004/obsesi.v1i2.22

Budiwibowo, S. (2013). Membangun Pendidikan Karakter Generasi Muda Melalui Budaya Kearifan Lokal di Era Global. Premiere Educandum : Jurnal Pendidikan Dasar Dan Pembelajaran, 3(01), 39-49. https://doi.org/10.25273/pe.v3i01.57

Cheung, C. kiu, \& Lee, T. yan. (2010). Improving Social Competence Through Character Education. Evaluation and Program Planning, 33(3), 255-263. https:// doi.org/10.1016/j.evalprogplan.2009.08.006

Darmayanti, S. E., \& Wibowo, B. U. (2014). Evaluasi Program Pendidikan Karakter di 
Sekolah Dasar Kabupaten Kulon progo. Jurnal Prima Edukasia, 2(2), 223234.https:/ / doi.org/10.21831/jpe.v2i2.2721

Fauzi, A., Zainuddin, Z., \& Atok, R. (2017). Penguatan Karakter Rasa Ingin Tahu dan Peduli Sosial melalui Discovery Learning. Jurnal Teori Dan Praksis Pembelajaran IPS, 2(2), 79-88. https:/ / doi.org/10.17977/ um022v2i22017p079

Ginanjar, M. H. (2017). Urgensi Lingkungan Pendidikan Sebagai Mediasi Pembentukan Karakter Peserta Didik. Edukasi Islami: Jurnal Pendidikan Islam, 2(04), 376-396. https:// doi.org/10.30868/EI.V2I04.37

Hendriana, E. C., \& Jacobus, A. (2017). Implementasi Pendidikan Karakter di Sekolah Melalui Keteladanan dan Pembiasaan. JPDI (Jurnal Pendidikan Dasar Indonesia), 1(2), 25-29. https://doi.org/10.26737/JPDI.V1I2.262

Hidayah, Y., Ahmad Dahlan, U., \& Author, C. (2018). Pendidikan Karakter Religius Pada Sekolah Dasar: Sebuah Tinjuan. Jurnal Iqra' : Kajian Ilmu Pendidikan, 3(2), 329344. https:// doi.org/10.25217/ji.v3i2.333

Ikranagara, P. (2015). Pemberian Reward dan Punishment Untuk Meningkatkan Kedisiplinan Siswa Dalam Pembelajaran IPS Kelas V SD Negeri 1 Kejobong Purbalingga. Jurnal Pendidikan Guru Sekolah Dasar, 4(2), 1-12. Google Scholar

Jumini, Ali, M., \& Miranda, D. (2015). Peningkatan Karakter Kepedulian Sosial Melalui Metode Bercerita Pada Anak Usia 5-6 Tahun. Jurnal Pendidikan Dan Pembelajaran Khatulistiwa, 4(4), 1-18. Google Scholar

Katilmis, A., Eksi, H., \& Ozturk, C. (2011). Efficiency of Social Studies Integrated Character Education Program. Educational Sciences: Theory and Practice, 11(2), 854859. Google Scholar

KPAI. (2019). Sepanjang 2019, KPAI Terima 153 Aduan Kekerasan Fisik terhadap Siswa. Google Scholar

Lizawati, L., \& Uli, I. (2018). Implementasi Nilai Pendidikan Karakter dalam Sastra Lisan Di IKIP PGRI Pontianak. Premiere Educandum: Jurnal Pendidikan Dasar Dan Pembelajaran, 8(2), 149. https:/ / doi.org/10.25273/pe.v8i2.2911

Ma`arif, M. A. (2018). Analisis Strategi Pendidikan Karakter Melalui Hukuman Preventif. Ta'allum: Jurnal Pendidikan Islam. https://doi.org/10.21274/taalum.2018.6.1.31-56

Marta, E. D. (2016). Implementasi Pemberian Reward kepada Siswa SD Muhammadiyah Bantul Kota. Jurnal Pendidikan Guru Sekolah Dasar. Google Scholar

Maunah, B. (2016). Implementasi Pendidikan Karakter dalam Pembentukan Kepribadian Holistik Siswa. Jurnal Pendidikan Karakter, 5(1), 90-101. https:// doi.org/10.21831/jpk.v0i1.8615

Octavia, Tri, E. (2019). Analisis Pendidikan Karakter Peduli Sosial Pada Siswa Kelas IV Tema Indahnya Keberagaman Di Negeriku SDN Kebonsari 2 Malang. Prosiding Seminar Nasional PGSD UNIKAMA, 3(1), 87-96. Google Scholar

Rofiq, M. H. (2017). Kedisiplinan Siswa Melalui Hukuman Perspektif Stakeholder Pendidikan. Nidhomul Haq: Jurnal Manajemen Pendidikan Islam, 2(2), 82-94. https:// doi.org/10.31538/nidhomulhaq.v2i2.29

Sari, Y. M. (2016). Pembinaan Toleransi dan Peduli Sosial dalam Upaya Memantapkan Watak Kewarganegaraan (Civic Disposition) Siswa. Jurnal Pendidikan Ilmu Sosial, 23(1), 15-26. https://doi.org/10.17509/jpis.v23i1.2059

Seftiana, D. (2019). Discipline Values Implementation in Fifth Grade Student of SD Negeri Sidakan, Kulon Progo in Year 2018/2019. BASIC EDUCATION, 1(13), 1299-1306. Google Scholar 
Sidauruk, V. A., \& Supeni, S. (2019). Peran Guru dalam Perencanaan, Pelaksanaan dan Evaluasi Pembelajaran PPKn Terhadap Pembentukan Karakter Disiplin. Jurnal Global Citizen: Jurnal Ilmiah Kajian Pendidikan Kewarganegaraan, 6(2), 35-48. Google Scholar

Sudrajat, A. (2011). Mengapa Pendidikan Karakter? Jurnal Pendidikan Karakter, 1(1), 4758. https://doi.org/10.21831/jpk.v1i1.1316

Tabi'in, A. (2017). Menumbuhkan Sikap Peduli pada Anak Melalui Interaksi Kegiatan Sosial. IJTIMAIYA: Journal of Social Science Teaching, 1(1), 39-59. https:// doi.org/10.21043/ji.v1i1.3100

\section{Copyright Holder :}

(C) Safitri, M.L.O., Mustadi, A., \& Retnawati, H. (2021).

First Publication Right :

(c) Jurnal Iqra' : Kajian Ilmu Pendidikan

This article is under:

\section{(ㅇ)(1) (2)}

